\title{
IMPLEMENTASI KEBIJAKAN PENGELOLAAN KEUANGAN DESA
}

\author{
Agustinus Ghunu ${ }^{1 *}$, Cahyo Sasmito ${ }^{2}$, Annisa Purwatiningsih ${ }^{3}$ \\ 1)Magister Administrasi Publik Universitas Tribhuwana Tunggadewi Malang \\ 2,3) Universitas Tribhuwana Tunggadewi Malang \\ *)Korespondensi: agusgh2020@gmail.com
}

\begin{abstract}
The purpose of this article is to analyze and describe the implementation of village financial management policies (ADD, DD and $D B H)$, as well as the supporting and inhibiting factors in the implementation of village community financial management policies (ADD, DD and $D B H$ ) intended to improve welfare and good governance. The implimentation of the management of village finances ( $A D D D D$ and $D B H$ ) creates negative phenomena or phenomena that is not on target. The research method is a qualitative descriptive approach. The results of the analysis, based on the Donald van Meter and Carl van Horn policy implementation model, indicates that five of the six variables affect the successful implementation of village financial management policies while one variable, namely the external environment, does not affect the successful implementation of village financial policies. The supporting factors are the existence of regulations, community participation, internal and external cooperation, while the obstacles are the regulations that often change and the delay in distribution to the RKD.
\end{abstract}

Article Histori:

Accepted: 10/9/2020

Review: $19 / 10 / 2020$

Publish: 30/4/2021

Keyword: Implementation, policy, village financial, prosperity, good governance

\section{PENDAHULUAN}

Proses penyelenggaraan pemerintahan yang baik, transparan dan akuntabel yaitu bagaimana menciptakan sistem birokrasi yang dapat menjalankan amanat dalam perwujudan rakyat yang adil, makmur dan sejahtera merupakan kebutuhan mendasar yang harus dipenuhi oleh penyelenggara pemerintahanan di semua tingkatan mulai dari tingkat pusat, daerah, maupun desa.

Menurut Solekhan (2014) bahwa upaya pemerintah pusat melalui kebijakan otonomi daerah sebagaimana diatur dalam
Undang-Undang Nomor 23 Tahun 2014 Tentang Pemerintahan Daerah yaitu memberikan otonomi kepada daerah agar dapat meningkatkan kualitas demokrasi, efisiensi pelayanan publik, percepatan pembangunan daerah untuk mewujudkan kesejahteraan rakyat dan menciptakan pemerintahan yang baik (good governance). Sebagai tindak lanjut dari kebijakan ini dan sebagai wujud nyata perhatian dan kepedulian pemerintah pusat kepada desa maka terbitlah Undang-Undang Nomor 6 Tahun 2014 Tentang Desa yang merupakan 
revisi dari peraturan sebelumnya sehingga desa memiliki hak otonom dan kewenangan mengelolah keuangan desa yang selanjutnya diikuti oleh Peraturan Pemerintah Nomor 60 Tahun 2014 Tentang Dana Desa dan Peraturan Menteri Keuangan Nomor 112/PMK.07.2017 Tentang Pengelolaan Transfer ke Daerah dan Dana Desa sebagai payung hukum pengelolaan keuangan desa. Kebijakan Dana Desa ini digulirkan setelah dikeluarkan kebijakan Alokasi Dana Desa (ADD) yang ditujukan untuk membiayai bidang pembangunan, pemerintahan dan pemberdayaan masyarakat desa dari RAPBD.

Mengacu pada permasalahan pengelolaan keuangan daerah, implementasi kebijakan pengelolaan keuangan desa memunculkan keraguan dan pertanyaan bagi banyak pihak. Permasalahan-permasalahan tersebut dapat menghambat tercapainya tujuan kebijakan keuangan desa, yaitu peningkatan kesejahteraan rakyat, pemerataan pembangunan desa dan terwujudnya pemerintahan yang baik dan akuntabel.

Permasalahan tersebut diantaranya telah terjadi banyak fenomena baik keberhasilan maupun kegagalan dalam pengelolaan keuangan desa tersebut, misalnya Dana Desa yang sangat besar jumlahnya itu berpeluang dan rawan dikorupsi. Sampai dengan saat ini, Dana Desa yang sudah disalurkan pemerintah berjumlah Rp 257 trilyun. Dana ini sudah disalurkan ke 74.954 desa di seluruh wilayah Indonesia, Primayoga (2018). Kondisi tersebut sebagaimana yang telah dijabarkan melalui tabel 1 yang menguraikan terkait realisasi dana desa sejak tahun 2015 sampai dengan tahun 2019 berdasarkan realisasinya.
Tabel 1. Realisasi Dana Desa Tahun 20152019 dan Rencana Realisasi 2020

\begin{tabular}{ccl} 
No & TAHUN & \multicolumn{1}{c}{ RP } \\
\hline 1 & 2015 & 20,67 triliun \\
\hline 2 & 2016 & 46,98 triliun \\
\hline 3 & 2017 & 60 triliun \\
\hline 4 & 2018 & 60 triliun \\
\hline 5 & 2019 & 70 triliun \\
\hline 6 & $2020^{*}$ & 72 triliun
\end{tabular}

Sumber: ICW, (2018)

Dengan demikian total Dana Desa dalam 5 tahun pertama pemerintahan Presiden Joko Widodo yang sudah direalisasikan sebesar Rp 257 triliun dan untuk lima tahun kedua (2019-2024) naik menjadi Rp 400 triliun, Riana \& Tri (2019). Sedangkan total Transfer Pusat ke Daerah dan Dana Desa dari tahun ke tahun mengalami peningkatan sebagai berikut:

Tabel 2. Transfer Pusat Ke Daerah dan Dana Desa (TKDD) Tahun 2015-2019 dan Perkiraan TKDD Tahun 2020

\begin{tabular}{ccc} 
No & TAHUN & RP (triliun) \\
\hline 1 & 2015 & 622 \\
\hline 2 & 2016 & 622 \\
\hline 3 & 2017 & 742 \\
\hline 4 & 2018 & 757,8 \\
\hline 5 & 2019 & 826,8 \\
\hline 6 & $2020^{*}$ & 856,9
\end{tabular}

Sumber: Kemenkeu, 2019

Sejak tahun 2015 sampai dengan semester pertama tahun 2018 hasil pengamatan ICW (Indonesia Corruption Watch) menunjukkan bahwa telah terjadi dari tahun ke tahun penyelewengan Dana Desa yang terus mengalami peningkatan. Telah ditemukan 181 masalah penyelewengan atau korupsi terhadap Dana Desa dan 184 telah dijadikan tersangka dengan total kerugian negara adalah $\mathrm{Rp}$. 40,6 miliar (Primayogha, 2018).

Berdasarkan penjelasan di atas, maka perlu untuk melakukan kajian dan analisis untuk mendeskripsikan bagaimana implementasi kebijakan pengelolaan keuangan desa (ADD, DD, DBH) serta faktor-faktor yang mendukung dan yang 
menghambat dalam rangka mendukung kebijakan penggunaan keuangan desa untuk meningkatkan kesejahteraan rakyat dan mewujudkan pemerintahan yang baik (good governance).

Untuk mewujudkan maksud dan tujuan tersebut di atas, maka Desa Karangwidoro dan Desa Kalisongo dipilih sebagai lokasi penelitian oleh karena tingkat kemiskinan di Desa Karangwidoro termasuk cukup tinggi. Dari 1860 KK (Kepala keluarga), sejumlah 182 KK tercatat sebagai Pra Sejahtera atau RTM/Keluarga Miskin penerima bantuan langsung tunai dan raskin. Mayoritas penduduk Desa Karangwidoro hanya mampu menyelesaikan sekolah di jenjang pendidikan wajib belajar sembilan tahun (SD dan SMP). Karena itu ketersediaan sumber daya manusia (SDM) yang memadai dan mumpuni merupakan tantangan tersendiri. Hal ini sejalan dengan hasil penelitian Dwinugraha (2017) bahwa sumberdaya manusia di desa menjadi tantangan tersendiri dari penyelenggaraan pemerintahan desa. Mata pencaharian sebagian besar penduduk Karangwidoro adalah petani, pedagang dan buruh industri sedangkan yang bekerja di bidang pemerintahan (PNS) sangat sedikit sekali. (Profil Desa Karangwidoro, 2019).

Demikian halnya dengan Desa Kalisongo tingkat perekonomian masyarakatnya Desa Kalisongo tergolong menengah ke bawah. Sebagian besar masyarakat Desa Kalisongo bekerja sebagai buruh, yaitu sebagai buruh kasar, buruh tani dan juga buruh pabrik, sedangkan yang bekerja di bidang pemerintahan (PNS) sangat sedikit sekali. Letak geografis Desa Kalisongo berdekatan dengan Desa Karangwidoro sehingga mempermudah dalam kegiatan penelitian sebagai upaya untuk menganalisis dampak dari implementasi pengelolaan keuangan desa di kedua desa tersebut sekaligus sebagai wawasan keilmuan dalam pengelolaan keuangan desa di Kabupaten Malang secara khusus dan Indonesia secara umum.

\section{KAJIAN LITERATUR}

Merumuskan proses penerapan/ implementasi kebijakan sebagai tindakantindakan yang dilaksanakan oleh perseorangan atau pejabat-pejabat atau kelompok pemerintah atau swasta untuk mencapai tujuan-tujuan yang telah ditetapkan dalam keputusan kebijakan (Wahap, 2017:135).

Sementara itu, (Winarno, 2016:135) berpendapat bahwa tugas penerapan/ implementasi ialah membuat suatu hubungan/jaringan untuk mempermudah tujuan-tujuan kebijakan bisa diwujudkan atau dilaksanakan sebagai akibat dari suatu kegiatan pemerintah. Dengan demikian tugas penerapan/implementasi adalah meliputi terbentuknya sistem penyampaian kebijakan (a policy delivery system), yaitu merancang dan menjalankan peralatanperalatan tertentu untuk mencapai tujuantujuan sesuai dengan harapan.

Implementasi kebijakan umum secara sederhana adalah sebagai suatu proses merealisasikan peraturan-peraturan ke dalam bentuk tindakan (action). Secara praktek/praktis pelaksanaan kebijakan publik merupakan suatu proses yang sangat kompleks dan terkadang bermuatan politis karena bentuknya intervensi berbagai kepentingan (Agustino, 2017:126).

\section{METODE PENELITIAN}

Adapun jenis penelitian yang digunakan dalam penelitian ini adalah metode penelitian kualitatif dengan pendekatan analisis deskriptif. Cara pengambilan data dilakukan secara langsung di lapangan penelitian melalui observasi/survey,wawancara, dokumentasi 
dan menggunakan instrumen penelitian seperti lembar daftar pertanyaan/panduan wawancara, lembar observasi (check list), dokumen, buku catatan, alat tulis, alat perekam, kamera, surat kabar, website/media on line, dan atau dokumen lain untuk mendapatkan informasi dan data yang diperlukan yang terkait dengan fokus penelitian ini.

Data pertama diperoleh dengan melakukan pengamatan di lapangan, dokumentasi di desa dan mewawancarai Perangkat Desa sebagai informan dan beberapa informan lainnya sesuai saran dari informan pertama dan seterusnya. Data sekunder diperoleh dari studi perpustakaan, BPS, Bappenas, media dan lembaga pemerintah lainnya.

Penelitian ini memiliki lingkup kajian yang meliputi pengelolaan Alokasi Dana Desa (ADD), Dana Desa (DD) dan Dana Bagi Hasil (DBH) di Desa Karangwidoro dan Desa Kalisongo, Kecamatan Dau, Kabupaten Malang.

\section{HASIL DAN PEMBAHASAN}

Dengan mengacu pada pola (model) penerapan/implementasi kebijakan Donald van Meter dan Carl van Horn dalam pelaksanaan/implementasi kebijakan pengelolaan keuangan desa (ADD, DD dan $\mathrm{DBH})$ dalam upaya meningkatkan kesejahteraan masyarakat dan Good Governance yang diajukan kepada perangkat Desa Karangwidoro dan Desa Kalisongo sebagai informan, maka adapun implementasi kebijakan pengelolaan keuangan desa, faktor-faktor pendukung dan penghambat dijabarkan lebih lanjutnya sebagai berikut:

\section{Implementasi Kebijakan Pengelolaan Keuangan Desa}

Dalam aspek Takaran dan Tujuan Kebijakan, diperoleh hasil bahwa kedua desa yang menjadi lokasi penelitian menunjukan pengelolaan keuangan desa yang dengan baik. Tujuan kebijakan dibuat dengan menyerap aspirasi dari bawah (bottom up) melalui Musyawarah Perencanaan Pembangunan pada tingkat dusun (MUSREMBANGDUS) dan Musyawarah Perencanaan Pembangunan pada tingkat Desa (MUSREMBANGDES) dengan memperhatikan regulasi dan kebijakan tingkat pusat, propinsi dan kabupaten (top-down) sehingga benar-benar menghasilkan sebuah tujuan kebijakan yang berhasil dan terukur misalnya dalam pengalokasian keuangan desa untuk pembangunan infastruktur dan lain-lain. Perencanaan Pengembangan dan Pembangunan Desa disusun dalam Rencana Pembangunan Jangka Menengah Desa (RPJMDesa) dan merupakan dokumentasi perencanaan pembangunan desa untuk masa 6 tahun sesuai dengan masa jabatan Kepala Desa yang terpilih. Ukuran tujuan kebijakan yang ditetapkan oleh pemerintah desa di kedua desa mempengaruhi pencapaian dari implementasi kebijakan pengelolaan keuangan desa. Oleh karena itu ke dua desa tersebut telah menyusun kebijakan-kebijakannya dengan tujuan dan dapat diukur tingkat keberhasilannya melalui mekanisme yang ada di masingmasing desa.

Berdasarkan aspek sumber daya , implementasi kebijakan dalam mengelola keuangan desa baik di Desa Karangwidoro maupun Desa Kalisongo terdukung dengan adanya sumberdaya yang meliputi (1) Sumber Daya Manusia,yang mana dilokasi penelitian telah memiliki kemampuan dan kinerja yang baik sesuai dengan bidangnya masing-masing. (2) Sumber Daya Finansial, (3) Sumber Daya Alam, dimana pencapaian program-program di kedua desa tersebut juga sangat didukung oleh ketersediaan sumber daya alam seperti air bersih, bahan baku dan sumber-sumber pendukung 
lainnya yang ternyata cukup tersedia di kedua desa tersebut. (4) Sumber Daya Waktu. Dimana di kedua desa tersebut sumber daya waktu telah diatur sedemikian rupa dalam pembuatan kebijakan sehingga tidak mengganggu atau menghalangi pencapaian implementasi kebijakankebijakan di kedua desa tersebut.

Merujuk kepada penelitian yang dilakukan, dalam merealisasikan keuangan desa yang jumlahnya sangat banyak memang bukan pekerjaan yang gampang. Dibutuhkan strategi, sejak dari penyusunan perencanaan, realisasi atau pelaksanaan perencanaan sampai dengan evaluasinya. Hal ini karena keuangan desa tersebut dimaksudkan untuk membangun desa agar desa dapat mandiri/berdikari, maju dan sejahtera. Dengan demikian dalam pengelolaannya keuangan desa harus dipastikan tidak salah sasaran atau diselewengkan melainkan sejalan dengan tujuan daripada alokasi dana desa itu sendiri (Saputra, 2016:7).

Berdasarkan aspek karakteristik Agen Pelaksana, lembaga formal dan informal telah dilibatkan dalam implementasi kebijakan publik. Disamping itu, ruang lingkup dan luas wilayah implementasi kebijakan telah dikalkulasi dengan cermat ketika menentukan agen pelaksana. Hal tersebut penting karena semakin luas ruang lingkup dan wilayah implementasi kebijakan, maka semakin banyak pula jumlah agen yang diikutsertakan (Agustino, 2017).

Kedua desa juga telah merujuk kepada ketentuan Peraturan Kepala Daerah Kabupaten Malang Nomor 38 Tahun 2018 tentang Pengelolaan Keuangan Desa pasal 7 yang mana dalam melaksanakan tugas sebagai perangkat desa, Kaur dan Kasi telah dibantu oleh TPK yang diusulkan saat penyusunan RPK Desa dengan keputusan kepala desa sebagai penguasa anggaran.
TPK tersebut terdiri dari Ketua, Sekretaris dan anggota. Pembentukan TPK ini oleh Kepala Desa dengan memperhatikan persyaratan dan karakteristik para pelaksana sehingga tujuan dari kebijakan dapat tercapai dengan baik untuk kesejahteraan masyarakat. Kondisi kedua desa telah sesuai dengan prinsip-prinsip pemerintahan yang baik dan berintegritas perlu diimplementasikan dalam pelayanan di sektor publik bidang pemerintahan menurut Juize (2013). Karakteristik dari agen pelaksana atau Tim Pelaksana Kegiatan dalam mengimplementasikan kebijakan pengelolaan keuangan desa di Desa Karangwidoro dan Desa Kalisongo dapat ditinjau dari karakteristik pendidikan dan karakteristik berbasis kinerja dan pengalaman kerja.

Tingkat pendidikan dari masingmasing pelaksana kebijakan di masingmasing desa berbeda-beda. Ada yang sarjana, diploma, SMA, dan SMP. Namun sebagian besar tingkat pendidikan pelakasana kebijakan adalah berpendidikan SMA. Sedangkan karakteristik berbasis kinerja dan pengalaman kerja dari pelakasana kebijakan adalah bahwa pelaksana kegiatan selalu berusaha untuk menyelesaikan kegiatan atau program kerja dengan tepat waktu, komitmen, transparan dan bertanggungjawab.

Pemahaman terhadap pentingnya pemerintahan yang baik (good governance), transparan, akuntabilitas, terbuka dan adil sesusai dengan kerangka hukum dan peraturan dalam implementasi kebijakan pengelolaan keuangan desa sangat diperhatikan dan ditaati baik oleh pembuat kebijakan maupun oleh pelaksana kebijakan di Desa Karangwidoro dan Desa Kalisongo. Dari hasil wawancara dan dokumentasi kegiatan sangat jelas komiteman dan integritas dari Kedua Desa ini untuk mewujudkan pemerintahan yang baik 
untuk kesejahteraan rakyat melalui pengelolaan keuangan desa yang terbuka, transparan, dan dapat dipertanggungjawabkan kepada masyarakat dan Inspektorat Kabupaten Malang sebagai mitra kerja pemerintahan desa dalam hal pemeriksaan dan pelaporan pengelolaan keuangan desa di kedua desa tersebut.

Tanpa adanya pemerintahan yang baik dan akuntabel, maka harapan untuk mewujudkan masyarakat yang sejahtera dan mandiri melelui pemberdayaan masayarakat desa dalam pengelolaan keuangan desa niscaya akan terwujud. Dengan demikian birokrasi yang baik,transparan, akuntabilitas, terbuka dan adil sesusai dengan kerangka hukum dan peraturan dalam implementasi kebijakan pengelolaan keuangan desa adalah salah satu faktor penting yang turut mempengaruhi berhasil atau tidak berhasilnya implementasi kebijakan pengelolaan keuangan desa.

Adapun bentuk nyata trasparansi pengelolaan keuangan desa di kedua desa tersebut adalah bahwa kedua desa tersebut sama-sama membuka informasi keuangan kepada masyarakat melalui pemasangan baliho/benner di depan kantor desa dan di lokasi pelaksanaan kegiatan serta penyusunan $\mathrm{RAB}, \mathrm{APBDes}$ yang transparan dan mengakomodir kepnetingan masyrakat serta penyusunan laporang pengelolaan keuangan yang akuntabilitas baik dalam lingkup internal maupun eksternal intansi dalam hal ini Inspektorat Kabupaten Malang.

Dari pembahasan di atas, tingkat pendidikan pelaksana kebijakan dan kinerja berbasis pengalaman kerja berpengaruh terhadap tingkat pemahaman dan kemampuan pelaksana kebijakan terhadap mekanisme dan kinerja serta pemahaman terhadap pentingnya pemerintahan yang baik (good governance), transparan, akuntabilitas, terbuka dan adil sesusai dengan kerangka hukum dan peraturan dalam implementasi kebijakan pengelolaan keuangan desa mempengaruhi keberhasilan implementasi pengelolaan keuangan desa di kedua desa tersebut.

Berdasarkan aspek sikap dan kecenderungan Para Pelaksana, Sikap penerimaan atau penolakan dari agen/pelaksana sangat mempengaruhi berhasil atau tidak berhasilnya kinerja pelaksanaan/implementasi kebijakan publik. Dari hasil penelitian, peneliti melihat keseriusan dan komitmen yang tinggi dari pemerintahan kedua desa untuk melaksanakan dan mengawal pelaksanaan kebijakan pengelolaan keuangan desa yang disalurkan untuk pembangunan dan kesejahteraan masyarakat desa.

Meskipun terjadi keterlambatan pencairan keuangan desa, tetapi kegigihan dan kerjasama baik internal dan eksternal pegawai desa memperlihatkan kecenderungan yang positif dan mendukung kebijakan implementasi pengelolaan keuangan desa tersebut. Hal ini sejalan dengan pernyataan bahwa pemerintahan yang baik di sektor publik adalah pemerintahan yang efektif dengan prinsip-prinsip mendorong pembuat keputusan menggunakan sumber daya secara efisien dan akuntabel. Dengan pemerintah yang baik dan berkarakter baik dapat meningkatkan perfoma kinerja yang baik, transparansi dan pencegahan terhadap terjadinya penyimpangan atau korupsi (Juize,2013).

Secara umum tim pelaksana kegiatan baik di Desa Karangwidoro maupun di Desa Kalisongo menunjukan sikap yang antusias dan mendukung implementasi kebijakan pengelolaan keuangan desa. Kesan ini peneliti dapati saat berinteraksi dengan semua informen, begitu semangat dalam menjawab pertanyaan ataupun memberikan 
penjelasan tentang kebijakan pengelolaan keuangan desa, bahkan salah satu dari mereka sempat menimpali diskusi agar jangan sampai ADD, DD dan DBH ini dihapus karena sangat terasa manfaatnya bagi masyarakat desa.

Dari pembahasan di atas, maka sikap dan kecenderungan (Disposition) para pelaksana atau tim pelaksana kegiatan mempengaruhi keberhasilan dari implementasi kebijakan keuangan desa di kedua desa tersebut.

Berdasarkan aspek Koordinasi dan komunikasi, dimana dua hal tersebut sangat penting untuk pencapaian tujuan kebijakan. Hal tersebut telah terlihat dan terjadi di kedua desa tersebut dimana komunikasi dan koordinasi antara perangkat dan pelaksana kegiatan berjalan baik demikian juga antara pemerintah desa dengan kecamata, kabupaten dan perbankan serta pihak eksternal lainnya terlaksana dengan baik. Sudah seharusnya, bahwa agar pembangunan desa dan penggunaan keuangan desa dapat berdampak positif bagi masyarakat desa maka diperlukan sinkronisasi antara program-program pembangunan di desa dengan kebijakan pembangunan di daerah (RPJM Daerah). Berdasarkan Undang-Undang Nomor 6/2014 Tentang Desa, Desa memiliki otoritas sangat luas ketika menentukan rencana, program pembangunan dan penggunaan keuangan desa sehingga daerah mengalami kesulitan mengintegrasikan kebijakan-kebijakan program pembangunan. Oleh karena itu dibutuhkan sinkronisasi dan sinergitas program kebijakan pembangunan desa dengan program kebijakan pembangunan daerah agar searah dan tujuan-tujuan dapat dicapai, (Buchari,2018). Dari hasil penelitian menunjukan bahwa komunikasi di kedua desa tersebut dilaksanakan baik secara formal maupun informal, lisan dan tulisan berupa surat menyurat dinas, naskah dinas, rapat koordinasi baik antar internal maupun eksternal intansi dan pihak terkait serta peninjauan langsung di lapangan.

Dari pembahasan di atas menunjukan bahwa koordinasi/komunikasi antar organisasi dan aktivitas pelaksana penerapan/ implementasi mempengaruhi penerapan/ implementasi kebijakan pengelolaan keuangan desa di Desa Karangwidoro dan Desa Kalisongo.

Berdasarkan aspek lingkungan sosial, ekonomi dan politik bahwa untuk mengevaluasi kinerja implementasi kebijakan publik, maka perlu memperhatikan seberapa jauh lingkungan luar (eksternal) turut menentukan kesuksesan kebijakan publik yang sudah diputuskan misalnya lingkungan sosial, ekonomi dan politik. Lingkungan yang kondusif akan menghasilkan kinerja penerapan/implementasi kebijakan yang berhasil namun sebaliknya lingkungan yang tidak kondusif dapat mempengaruhi ketidakberhasilan dari kinerja penerapan/implementasi kebijakan. Dengan demikian kondusifnya kondisi lingkungan eksternal sangat penting diperhatikan agar implementasi kebijakan dapat berhasil mencapai tujuan-tujaun yang telah ditetapkan, (Agustino, 2017). Meskipun secara nasional pertumbuhan ekonomi kita stagnan pada angka, 5,1\%, adanya Pilpres serentak dengan Pileg dan juga Pilkada Kabupaten Malang pada waktu yang lalu namun faktor-faktor eksternal tersebut tidak mempengaruhi atau menghambat pencapaian implementasi kebijakan pengelolaan keuangan desa di kedua desa tersebut. Bahkan partisipasi masyarakat sangat tinggi dalam mendukung teresalisasinya kebijakankebijakan dan program-program dari desa kedua desa tersebut. 
Faktor pendukung dan penghambat Implementasi Kebijakan Pengelolaan Keuangan Desa

Faktor-faktor yang mendukung implementasi kebijakan pengelolaan keuangan desa adalah yang pertama, partisipasi dan sambutan positif masyarakat terhadap program-program dari desa. Partisipasi masyarakat merupakan faktor penting dalam penyusunan kebijakan baik dari tahapan perencanaan, tahapan pelaksanaan, hingga tahapan pengawasan yang melibatkan masyarakat itu sendiri, tokoh-tokoh masyarakat, tokoh-tokoh agama, kelompok ibu-ibu PKK, kelompok Karang Taruna dan lain-lain. Partisipasi masyarakat tersebut sangat terasa di kedua desa penelitian ini. Kedua, Kerjasama internal dan eksternal instansi. Kerjasama internal yaitu kerjasama antar Kepala Desa dengan Perangkat Desa dan kerjasama eksternal intansi merupakan faktor pendukung yang juga sangat penting dan mendukung pencapaian implementasi kebijakan pembangunan desa. Hal inipun dapat ditemukan di kedua desa tersebut, adanya kerjasama, komunikasi dan koordinasi internal dan ekternal yang baik. Ketiga, Regulasi pemerintah. Regulasi pemerintah baik pemerintah pusat, propinsi, kabupaten maupun permerintah desa beserta aturan-aturan lain yang sangat membantu dan menjadi acuan dalam implementasi pengelolaan keuangan desa.

Keempat adalah Adanya Musyawarah Perencanaan Pembangunan Dusun (MUSDUS) dan Musyawarah Perencanaan Pembangunan Desa (MUSDES). Pelaksanaan Musrembang Dusun dan Musrembang Desa merupakan faktor pendukung penting untuk menghasilkan sebuah kebijakan yang benar-benar dapat memenuhi kebutuhan masyarakat sebab masyarakat secara langsung terlibat dalam memberikan usul-usulan program-program yang tepat sasaran. Dari aspirasi masyarakat ini menjadi bahan penyusunan RPD (Rencana Pembangunan Desa) yang ditandatangani oleh semua pihak terkait antara lain: Ketua BPD, Ketua LPMD dan Kepala Desa serta disahkan oleh Camat dengan dilampiri Lembaran Kerja.

Kelima adalah Letak geografis desa dan potensi desa. Letak geografis dan potensi sumber daya alam di kedua desa tersebut menjadi faktor-faktor pendukung terutama karena kedua desa tersebut berbatasan dengan Kota Malang dan Kota Batu dan jalan alternatif dari Kota Malang ke Batu demikian sebaliknya memiliki potensi pariwisata yang dapat menjadi alternatif kunjungan pariwisata khususnya bagi wisatawan yang telah jenuh dan ingin mengunjungi pariwisata alternatif di daerah lain termasuk di Desa Karangwidoro dan Desa Kalisongo.

Faktor-faktor yang menghambat implementasi kebijakan pengelolaan keuangan desa meliputi yang pertama adalah waktu atau jadwal pencairan dana yang lama atau molor dari jadwal. Dari hasil wawancara dengan Kepala Desa Karangwidoro keterlambatan pencairan dana dari jadwal yang seharusnya sangat mempengaruhi pelaksanaan dari kebijakankebijakan di desa. Progam kerja sudah dimulai di bulan Januari tetapi penyaluran tahap I baru ditransfer ke Rekening Keuangan Desa (RKD) pada awal bulan Juli. Untuk mengatasi masalah keterlambatan penyaluran dana ini ke RKD, maka Kepala Desa melaksanakan pembiayaan dengan dana pribadi untuk operasional dan untuk hal yang sangat mendesak seperti pembelian bahan bangunan maka, pihak penyedia bahan bangunan memberikan kemudahan dengan cara dihutangi dulu dan sesudah ada pencairan baru dibayarkan belakangan. 
Berikutnya adalah Regulasi/aturan penggunaan dana desa yang sangat ketat. Penyusunan dan pelaporan realisasi penyaluran dana membutuhkan waktu namun terkadang waktu yang tersedia tidak mencukupi oleh karena keterlambatan penyaluran dana sehingga saat dana ditransfer bulan Juli, harus segera membuat laporan realisasi tahap I dan sekaligus penyusunan pengajuan untuk tahap II yang juga cair terlambat sekitar diantara bulan Agustus hingga bulan November sementara di bulan November-Desember saatnya MUSDUS, MUSDES, penyusunan RPD, RAPBDes hingga menjadi APBDes.

\section{PENUTUP}

Berdasarkan hasil penelitian yang telah dilaksanakan dan dari hasil pembahasan sebelumnya maka dapat disimpulkan bahwa implementasi kebijakan pengelolaan keuangan desa di Desa Karangwidoro dan Desa Kalisongo, telah dilaksanakan sesuai dengan peraturan dan UU yang berlaku, tepat sasaran dan sangat memenuhi kebutuhan masyarakat, memahami pentingnya melaksanakan pemerintahan yang baik (good governance), transparan, akuntabilitas, terbuka dan adil. Tingkat penyerapan dana cukup baik dalam implementasi kebijakan pengelolaan keuangan desa di Desa Karangwidoro pada tahun 2015 sebesar Rp. 892.906.134 terserap $100 \%$ atau efektif, tahun 2016 sebesar Rp. 1.259.248.200 terserap $84,55 \%$ atau cukup efektif, tahun 2017 sebesar Rp. 1.489.298.841 terserap 106,05\% atau sangat efektif, tahun 2018 sebesar Rp. 1.727.257.504 terserap $119,90 \%$ atau sangat efektif dan tahun 2019 sebesar Rp. 1.743.983.452 terserap 116,82\% atau sangat efektif. Sedangkan di Desa Kalisongo pada tahun 2015 sebesar Rp. 1.049.690.333 terserap 100\% atau efektif, tahun 2016 sebesar Rp. 1.320.526.854 terserap $100,09 \%$ atau sangat efektif, tahun
2017 sebesar Rp. 911.704 .400 terserap 67,26\% atau kurang efektif, tahun 2018 sebesar Rp. 1.749.173.572 terserap $105,21 \%$ atau sangat efektif dan tahun 2019 sebesar Rp. 1.919.401.169 terserap $115,73 \%$ atau sangat efektif.

Adapun faktor-faktor yang mendukung implementasi kebijakan penggunaan keuangan desa di Desa Karangwidoro dan Desa Kalisongo adalah partisipasi semua unsur lapisan masyarakat, kerjasama internal dan eksternal instansi, regulasi pemerintah, adanya Musyawarah Perencanaan Pembangunan Dusun (MUSDUS), Musyawarah Perencanaan Pembangunan Desa (MUSDES) setiap tahunnya dan letak geografis desa serta potensi desa. Sedangkan faktor-faktor penghambat dalam implementasi kebijakan pengelolaan keuangan desa di Desa Karangwidoro dan Desa Kalisongo adalah waktu atau jadwal pencairan dana yang lama atau terlambat dari jadwal yang telah direncanakan dan regulasi/aturan penggunaan dana desa yang sangat ketat dan yang sering dirubah antar lintas Kementerian.

Dari kesimpulan di atas, maka dapat diberikan saran-saran baik kepada Desa Karangwidoro maupun Desa Kalisongo agar menghidupkan kembali BUMDes yang telah dibentuk sehingga dapat menjadi badan usaha yang menggerakan perekonomian masyarakat. Karena BUMDes mengambil peran yang besar di desa tersebut. Kemudian informasi terkait pengelolaan keuangan desa dalam bentuk banner sangat diperlukan sebagai sumber keterbukaan informasi.

\section{DAFTAR PUSTAKA}

Administrasi Pemerintahan Desa (profil desa) Karangwidoro, 2014-2019, Kumpulan RPMJDes, RKPDes, APBDes, 
SK Kepala Desa, Arsip Desa Karangwidoro.

Administrasi Pemerintahan Desa Desa (profil desa)Kalisongo, 2014-2019, Kumpulan RPMJDes, RKPDes, APBDes, SK Kepala Desa, Arsip Desa Kalisongo.

Antoh, A. E. (2017). Pengaruh Manajemen Aset dalam Optimalisasi Aset Tetap (Tanah dan Bangunan) Pemerintah Daerah (Studi di Kabupaten Paniai). Jurnal Manajemen \& Bisnis, 1(2), 37-47.

Agustino, Leo (2017). Dasar-dasar Kebijakan Publik. Penerbit Alfabeta Bandung.

Buchari, RD Ahmad., Sumaryana, Asep., Rusli, Budiman., \&. Jamaluddin, Yanhar. (2018). Analisis Dampak Pengelolaan dan Penggunaan DD Terhadap Pembangunan Daerah. Jurnal Ilmu Pemerintahan dan Sosial Politik UMA Volume 6, No. 1.

Dwinugraha, A. P. (2017). Sinergitas Aktor Kepentingan Dalam Penyelenggaraan Pemerintahan Desa (Studi pada Desa UrekUrek Kecamatan Gondanglegi Kabupaten Malang). PUBLISIA (Jurnal Ilmu Administrasi Publik), 2(1), 1-7.

Juiz, Carlos., Guerrero, Carlos., \& Lera,Isaac. (2014). Implementing Good Governance Principles for the Public Sector in Information Technology Governance Frameworks. Open Journal of Accounting, Volume 3.
Primayogha, Kompas.com, 21/11/2018, "ICW: Ada 181 Kasus Korupsi Dana Desa, Rugikan Negara Rp 40,6 Miliar", diunduh tanggal 16 Oktober 2019 dari https://nasional.kompas.com/read/20 18/11/21/19000481/icw-ada-181kasus-korupsi.

Riana, Friski \& Tri, Rahma, 2019, Tempo.com, Senin, 15 Juli 2019, Periode II Jokowi, Alokasi Dana Desa Naik Jadi Rp $\quad 400 \quad$ Triiliun https:// bisnis.tempo.co/read/1224878 /periode-ii-jokowi-alokasi-dana-desanaik-jadi-rp-400-triiliun diundu 16 Oktober 2019.

Saputra, I Wayan. (2016). Efektivitas Pengelolaan ADD Pada Desa Lembean Kecamatan Kintamani, Kabupaten Bangli Tahun 2009-2014. Jurnal Jurusan Pendidikan Ekonomi, Volume 6, No.1.

Solekhan, Moch. (2014). Penyelenggaraan Pemerintahan Desa. Penerbit Setara Press. Malang.

Sukanto, Azwardi. (2014). Efektivitas ADD dan Kemiskinan di Propinsi Sumatera Selatan. Jurnal Ekonomi Pembangunan Volume 12, No. 1.

Wahab, H. Solichin Abdul. (2017). Analisis Kebijakan, Penerbit PT. Bumi Aksara, Jakarta.

Winarno, Budi. (2016). Kebijakan Publik Era Globalisasi. Penerbit CAPS. Yogyakarta. 